\title{
The association of DNA Repair with breast cancer risk in women. A comparative observational study
}

\author{
Jaime Matta ${ }^{1 *}$, Miguel Echenique ${ }^{2}$, Esperanza Negron ${ }^{1}$, Luisa Morales ${ }^{1}$, Wanda Vargas ${ }^{1}$, Felipe Sánchez Gaetan ${ }^{3}$, \\ Eduardo Ramírez Lizardi ${ }^{4}$, Aníbal Torres ${ }^{5}$, Jose Ortiz Rosado ${ }^{6}$, Guillermo Bolaños ${ }^{7}$, Juan González Cruz ${ }^{3}$, \\ Joaquín Laboy ${ }^{8}$, Ricardo Barnes ${ }^{8}$, Santos Santiago Medina ${ }^{9}$, Ángel Romero ${ }^{4}$, Rosendo Martinez ${ }^{3}$, Julie Dutil ${ }^{10}$, \\ Erick Suarez $^{11}$, Carolina Alvarez-Garriga ${ }^{12,13}$ and Manuel Bayona ${ }^{12,13}$
}

\begin{abstract}
Background: Previous studies have found a link between a low DNA repair capacity (DRC) level and increased cancer risk. Our aim was to assess the statistical association of DRC level and breast cancer (BC) using a casecontrol epidemiological study in a Hispanic community.

Methods: We conducted a comparative observational study to assess the validity of DRC in detecting BC in 824 women throughout Puerto Rico. Over a 6-year period, we compared 285 women newly diagnosed with BC to 539 without BC. DRC levels were measured in lymphocytes by means of a host-cell reactivation assay. We assessed the sensitivity, specificity, and association using the receiver operating characteristic curve analysis. Multiple logistic regression-adjusted odds ratios were estimated with 95\% confidence level to measure the strength of the association of DRC and BC after adjusting for all confounders simultaneously.

Results: Compared to women without cancer, women with BC showed an average decrease of $60 \%$ in their DRC levels $(p<0.001)$. Validity of the association of DRC as a measure of BC risk showed a sensitivity of $83.2 \%$ and specificity of $77.6 \%(p<0.0001)$.
\end{abstract}

Conclusions: Our results support the usefulness of DRC level as a measure of BC risk. Additional studies in other populations are needed to further verify its usefulness.

Keywords: Breast cancer, DNA repair capacity, Association, Risk, Biomarker

\section{Background}

Breast cancer (BC) is the most common cancer worldwide affecting women, accounting for $20 \%$ of all malignancies in females [1]. In 2010, an estimated 207,090 U. S. women were diagnosed with BC [2]. In Puerto Rico, BC accounted for $30 \%$ of all cancers in 2009. This percentage represented 1,776 new patients, which was the highest incidence per organ (Cancer Registry of Puerto Rico). Despite the declining trend in mortality, $\mathrm{BC}$ is currently the second leading cause of cancer death in women living in the U.S. and the first cause of cancer mortality in Puerto Rican women [3]. Even with the

\footnotetext{
*Correspondence: jmatta@psm.edu

'Department of Pharmacology, Physiology, and Toxicology, Department of Surgery, Ponce School of Medicine and Health Sciences, Ponce, Puerto Rico 00732

Full list of author information is available at the end of the article
}

many advances made in diagnostic procedures and treatments for BC, early-detection methods are needed.

Because age is a principal risk factor for cancer, studies on aging have provided additional understanding of DNA repair processes [4]. However, aging is not the only cause of genomic instability that can lead to cancer. Individuals vary in their inherent sensitivities to mutagens and carcinogens due to differences in their DNA repair capacity (DRC) levels [5]. Several studies have shown that lower DNA repair capacity correlates with higher cancer risk [6-18]. Epidemiological studies using functional repair assays in lymphocytes have also demonstrated that DRC varies greatly among individuals, and that a low DRC is a significant risk factor for the development of several types of cancer [9,12,14,17,19-21].

With respect to DNA repair in cases of $\mathrm{BC}$, the Nucleotide Excision Repair (NER) pathway is receiving

\section{Biomed Central}


increasing attention [22]. Numerous studies using lymphocytes have demonstrated an association between $\mathrm{BC}$ incidence and NER deficiency [11,23-28]. Collectively, they suggest that NER deficiency may contribute to the etiology of sporadic and familial BCs. If we can learn more about that association and develop a readily available clinical method for detecting DRC, then we can identify, treat, and arrest BCs earlier.

The aim of our study was to to assess the statistical association of DRC level and breast cancer (BC) using a case-control epidemiological study in a Hispanic community. In contrast to previously published studies, including our (Ramos et al. 2004), we used a large sample size (824 participants) for increased statistical power. This clinic-based, observational study [29] compared recently diagnosed, treatment-naïve, histopathologically confirmed $\mathrm{BC}$ patients to women without $\mathrm{BC}$.

\section{Methods}

\section{Epidemiologic design}

Over a 6-year period, we recruited 824 women of Hispanic origin, age 21 or older: 285 women newly diagnosed with $\mathrm{BC}$ and 539 without $\mathrm{BC}$. Calculations of sample size done initially revealed that a sample size of 824 participants (312 women with $\mathrm{BC}, 515$ women without $\mathrm{BC}$ ) would allow us to have a statistically significant odds ratio as low as 1.7 when the percent exposed to a low DRC among controls is $15 \%$ or higher (e.g., $15 \%$ controls are 21 to 30 years of age) with 5\% significant level and $80 \%$ of statistical power.

The population represents a genetically diverse population that is an admixture of European, African, and Amerindian ethnic groups (per studies from 106 ancestry markers-Dr. Julie Dutil, unpublished observations). Women who were obtaining mammograms and other routine gynecological and primary care/screening services at the same medical offices where patients with $\mathrm{BC}$ were being treated were recruited consecutively at the following locations: Ponce School of Medicine and Health Sciences Outpatient Clinic, Auxilio Mutuo Hospital (San Juan), Damas Hospital (Ponce), and St. Luke's Hospital (Ponce), as well as Yauco and other selected collaborating cities throughout Puerto Rico, representing 65 (83\%) of the 78 municipalities (counties) on the island. Because Puerto Rico offers universal health insurance coverage, any healthy women who might develop $\mathrm{BC}$ would be treated in the same facilities where $\mathrm{BC}$ patients were recruited. This selection procedure minimized selection bias due that could have otherwise been a factor (site, screening/treatment modalities) if healthy women were recruited from the general population by other means (e.g., through randomdigit dialing, as noted by Rothman et al. [30]).

This study was approved by the IRB of the Ponce School of Medicine and Health Sciences (Ponce, Puerto
Rico) and participating hospitals. Informed consent was obtained from all participants before interviewing them, drawing blood samples, collecting tumor material, and obtaining pathology reports.

The two main inclusion criteria for selecting women without $\mathrm{BC}$ were 1 ) a normal breast examination done by a primary care physician and 2) a normal mammogram, both within the last six months. These criteria reduced the likelihood of the existence of undiagnosed $\mathrm{BC}$ in this cohort.

We studied only recently diagnosed, treatment-naïve $\mathrm{BC}$ patients with primary tumors. Exclusion criteria included those with metastatic $\mathrm{BC}$, secondary $\mathrm{BC}$, breast metastases from another type of cancer, or any acquired or genetic immunodeficiency. Because blood transfusions, chemotherapy, and radiotherapy can significantly affect DRC [31-33], patients who had received any of those treatments in the past 5 years were also excluded from the study.

Pathology reports from all patients were obtained to confirm the 1) diagnosis, 2) tumor grade, 3) tumor size, 4) presence or absence of axillary lymph node metastasis, and 5) other clinically relevant information. An epidemiological questionnaire soliciting information and variables related to $\mathrm{BC}$ risk was provided to each participant.

\section{Blood collection and isolation of lymphocytes from women} Approximately $30 \mathrm{~mL}$ of peripheral blood was obtained from each participant and stored in heparinized tubes. The lymphocytes were then isolated by the Ficoll gradient technique and suspended in $2 \mathrm{~mL}$ of freezing media containing 10\% dimethyl sulfoxide, 40\% RPMI 1640 medium, $50 \%$ fetal bovine serum, and $1 \%$ antibiotic/antimycotic. Aliquots were stored in a $-80^{\circ} \mathrm{C}$ freezer for $1-3$ weeks. The lymphocytes were later thawed in batches of 5-7 samples for the host-cell reactivation (HCR) assays (details follow). Collection periods were approximately the same for patients and women without $\mathrm{BC}$ because recruitment was conducted concurrently.

\section{Plasmid preparation for host cell reactivation (HCR) assay for measuring DNA repair capacity}

The late Dr. Lawrence Grossman (Johns Hopkins School of Public Health, Baltimore, MD) provided the luciferase plasmid for the HCR assay and the protocol for its use. A non-replicating plasmid expression vector (pCMVluc) of 4,863 base pairs was genetically engineered to contain a bacterial luciferase reporter gene that is not present in a mammalian cell. The gene was damaged by ultraviolet $\mathrm{C}$ radiation $(254 \mathrm{~nm})$ exposure in a controlled, quantitative manner (dose-response curve) so that the level of its expression was a direct measure of the repair capacity of the host mammalian cell. The plasmid construct containing the luciferase gene (LUC) was irradiated at 0,350 , and 700 
$\mathrm{J} / \mathrm{m} 2$ using a 254-nm UVC lamp [11]. This plasmid construct and its validation have been described previously [34]. The controlled, quantitative UV exposure produced a dose-response curve so that the level of its expression was a direct measure of the repair capacity of the host mammalian cell.

\section{HCR assay to measure DRC}

The HCR assay that we utilized to measure DRC levels in lymphocytes has been described in previously published molecular epidemiological studies of cancer [9,11,12,34-37]. This assay measures the total DRC of transfected lymphocytes. Results reflect the host cells' overall repair capacity, although HCR primarily detects activity of the nucleotide excision repair (NER) pathway [38].

To assess this assay's precision, we used a data subset that involved duplicates of 50 women with BC, 50 women without $\mathrm{BC}$, and 90 samples of three commercial cell lines. A correlation of 0.97 (95\% overall confidence interval: $0.95-1.00)$ was found $(P<0.001$; data not shown). In addition, we repeated the assay if we found any inconsistencies between duplicates.

The measurement of DRC has a coefficient of variation of $23 \%$ in the data presented in this study. A batch effect associated with inter-technician variability in performance of the DRC assay was found; this was corrected by excluding 36 samples (35 BC cases, 1 control). Grossman and Wei [5] demonstrated that, at this precision, our assay can distinguish both intra- and inter-assay variation by being able to maintain the ranks of DRC values in samples measured in triplicate from multiple patients.

\section{Validation of stable transfection}

To confirm achievement of stable transfection, we utilized the Dual-GloR ${ }^{\circledR} \quad$ Luciferase Assay System (Promega; Madison, WI), which is based on the combined use of the Firefly and Renilla luciferases proteins as co-reporters. The assay allows for analysis of mammalian cells (e.g., lymphocytes) containing genes for Firefly and Renilla luciferases grown as positive controls. To determine whether our results would vary significantly between cryopreserved versus fresh blood samples, we took dual samples from 5 patients (total of 10 blood samples) and assayed 5 immediately after phlebotomy (fresh), then cryopreserved the other 5 samples at $-80^{\circ} \mathrm{C}$ and analyzed those several weeks later.

\section{Preparation of samples and controls}

Previously frozen peripheral blood lymphocytes from patients and women without $\mathrm{BC}$ were assayed in batches, as described by Ramos et al. [11]. Peripheral blood lymphocytes with $>95 \%$ viability were incubated for $72 \mathrm{~h}$ with phytohemagglutinin and then were transfected with undamaged or damaged plasmid DNA. Cells isolated from xeroderma pigmentosum patients corresponding to complementation groups $\mathrm{C}$ and $\mathrm{D}$ (XPC, XPD) were used as positive controls (cell lines GM 02246D and GM 02253F, respectively; Coriel Institute Medical Research; Camden, NJ).

\section{Calculation of DRC}

The assay for the gene expression of luciferase activity was measured using a luminometer (Turner Designs, model TD-20/20, Sunnyvale, CA). The percentage of DRC was calculated as the percentage of luciferase activity present after the repair of damaged plasmid DNA, compared to the DRC of undamaged plasmid DNA (100\%). This method produced a range of DRC values from nearly 0 to $19 \%$ DRC.

\section{Statistical analyses}

The association of DRC levels was based on the accuracy detecting $\mathrm{BC}$ when a woman has a high versus low DRC level. Data analyses were conducted by using the IBM SPSS statistical package version 17.0 (IBM; Armonk, N.Y.). The Wilcoxon or Mann Whitney $U$-test for independent samples was used to assess the statistical significance of the mean difference to account for non-normally distributed variables such as in DRC [39].

During crude analysis, variables such as DRC, age, weight, and body mass index, were first analyzed as continuous variables. The mean difference was used to assess DRC and anthropometric difference between patients with $\mathrm{BC}$ and women without $\mathrm{BC}$ using the logistic regression model [39]. After this step, for stratified analysis, continuous variables were categorized by using percentiles as cutoff points [29]. DRC was divided in low and high DRC using the median from the whole sample, also to divide on low, medium and high DRC, terciles were used from the whole data. Stratified analyses were conducted to identify and assess potential confounders or interaction effects of the association between BC and DRC $[29,30]$. After stratified analyses, a multivariable logistic regression model was used, odds ratio was estimated with 95\% confidence level to assess the strength of the association between DRC level and BC adjusting for potential confounders [30].

\section{Results}

Association between DNA Repair capacity levels and population variables in women with and without breast cancer

Women with $\mathrm{BC}(\mathrm{n}=285)$ had a mean DRC of $2.40 \%$; this was $60 \%$ lower than the average DRC level $(P<0.001$, Mann Whitney $U$-test) than in the 539 women without $\mathrm{BC}$, they had a mean DRC level of $6.13 \%$ (Figure 1). For every $1 \%$ decrease in DRC, there was $64 \%$ greater likelihood of having $\mathrm{BC}$. These findings were statistically significant $(\mathrm{p}<0.05)$. ROC curve analysis $[40,41]$ was used to assess the 


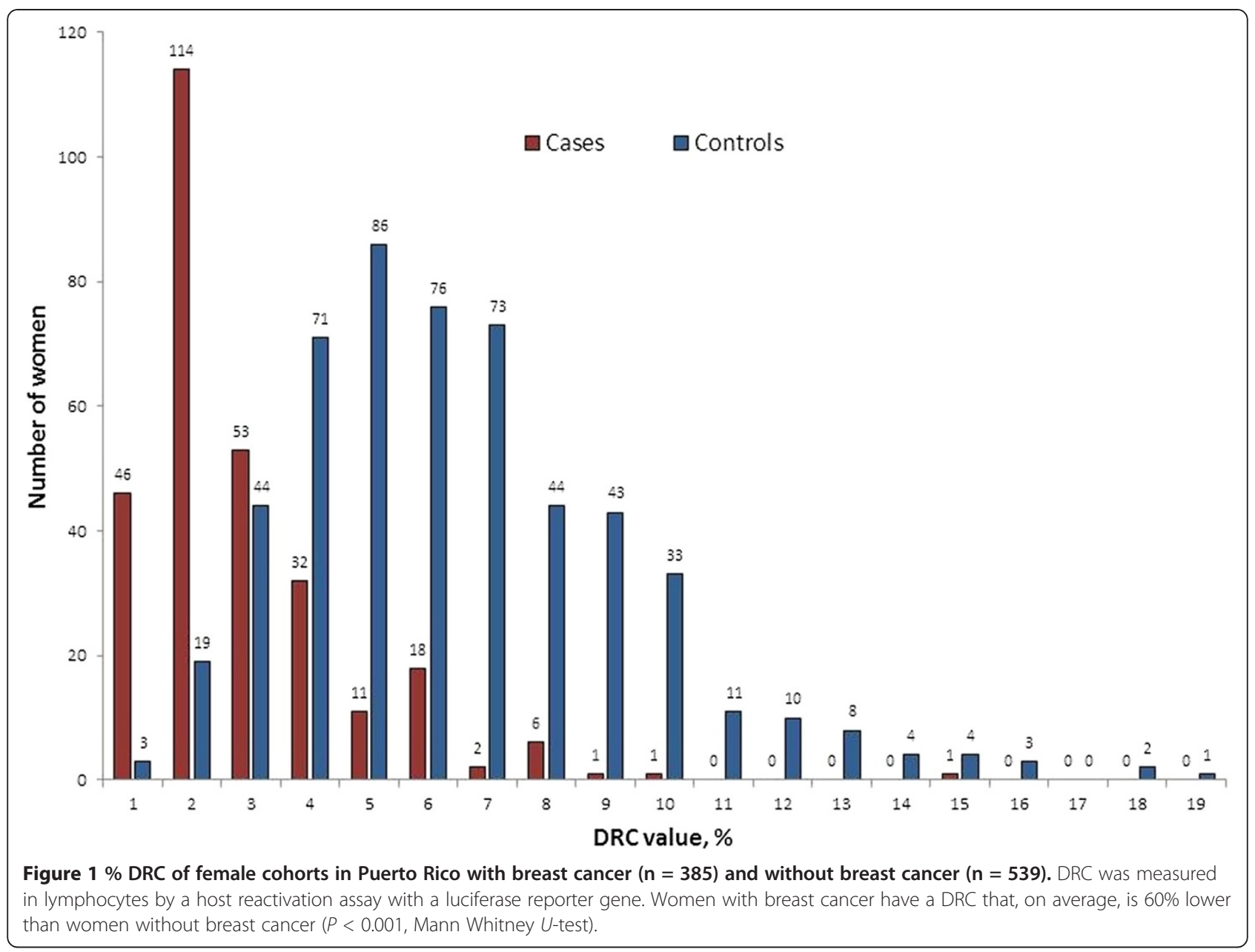

accuracy of detecting BC with DRC [42]. The area under the ROC curve was found to be $88.4 \%$ (95\% CI: $86 \%$, $90.9 \%$ ), and the $3.7 \%$ DRC cutoff point reached $83.2 \%$ sensitivity and $77.6 \%$ specificity (Figure 2 ).

Table 1 presents the crude and multivariate adjusted odds ratios to determine the strength of the associations between BC and other selected variables. Different blocks of variables were tested to find the best model for adjusting for potential confounding. The model that was finally used included, age, body-mass index, marital status, number of children, family history of $\mathrm{BC}$, and smoking. The odds of having BC increased $2 \%$ with every year of age (95\% CI: 1.01, 1.05). A family history of $\mathrm{BC}$ increased the odds of having BC by 1.7 times ( $95 \%$ CI: 1.0, 2.8). Interesting but statistically not significant findings included the following: the odds of having $\mathrm{BC}$ increased $10 \%$ with the birth of each child, $3 \%$ by each percent increase in BMI, $40 \%$ by history of pregnancy and $10 \%$ by smoking, also, for breastfeeding or alcohol intake; those decreased the odds for BC by $20 \%$, respectively. Compared to married women, widows had 4.6 times higher odds of having BC (95\% CI:1.6, 13.7); single women had 5.9 times higher odds of having BC (95\% CI: $2.3,15.6)$, and divorced had 3.6 times more likelihood of having BC (95\% CI: 1.2, 10.5).

Table 2 presents the crude and multivariate adjusted associations between BC and DRC. When DRC was analyzed as a continuous variable the adjusted odds ratio was 2.3 (95\% CI: 2.0, 2.6) $(P<0.001)$. The associations between BC and DRC, both as a continuous and as a categorical variable, became stronger after multivariate adjustment $(P<0.001)$. The DRC in three categories levels showed a strong association with $\mathrm{BC}$ and a statistically significant linear trend $(P<0.001)$. Women with low DRC levels $(\leq 3.0 \%)$ had 60.6 (95\% CI: 32.0, 114.6) times the odds of having $\mathrm{BC}$ as women with high DRC levels $(\geq 5.81 \%$ ) when adjusting for potential confounders.

\section{Discussion}

While the HCR assay as described in this study assesses the overall DNA repair capacity, it preferentially measures repairs made by the nucleotide excision repair (NER) pathway. NER repairs bulky adducts caused by 


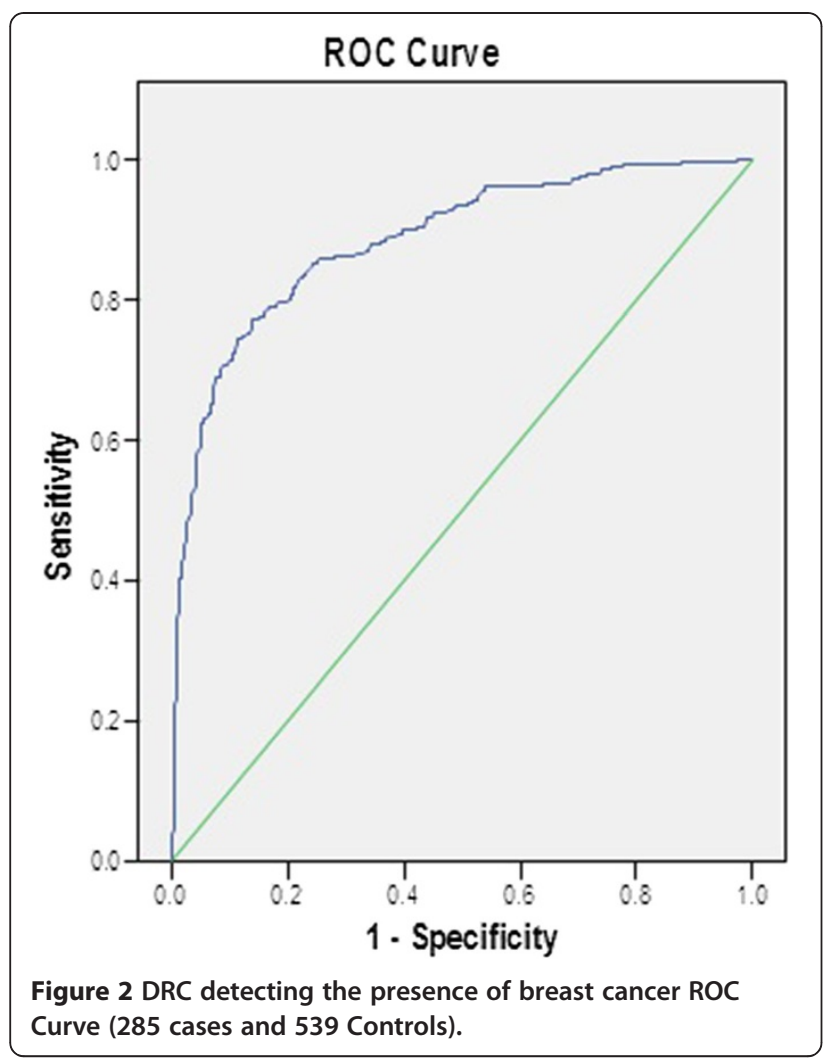

UV irradiation [38] and many carcinogens such as the ones contributing to carcinogenesis presented by $\mathrm{BC}$ patients [5-8]. Low levels of NER repair have been detected in peripheral blood lymphocytes and tumor samples of $\mathrm{BC}$ patients [5-8]. In addition, exposure to ionizing radiation is a risk factor for $\mathrm{BC}$ [9]. DNA lesions arising from ionizing radiation and many carcinogens causing bulky lesions are repaired by NER and deficiencies in the NER pathway can increase genomic instability.

The HCR assay, developed in the early 1990s, provided a way to obtain a quantitative, phenotypic measurement of DRC in lymphocytes [5]. The subsequent development of a plasmid based on luciferase activity instead of radioactivity resulted in stable transfection efficiencies [38]. Because of the high cost of this assay, its technical complexity, and its labor intensiveness, relatively few laboratories in the world currently utilize it for large-scale molecular epidemiology studies of cancer $[9,11,14,15,17,36,37,43]$.

Studies published to date of HCR assays of lymphocytes have frequently, but not always [34], found a link between a low DRC and increased cancer risk. Our group [11] was the first to report that a low DRC was a risk indicator for BC. That initial DRC study consisted of a small sample size ( $\mathrm{n}=36$ patients) and did not have the benefit of ROC analysis or a well-defined percent DRC level (e.g. low, medium, high) as a BC risk estimator compared to the analyses presented in this study. In the current study, we furthered classified DRC into terciles; low, medium and high levels. This methodology has the potential to serve as a biomarker of risk of $\mathrm{BC}$ (United States Patent Trade Office US 8,163,473 B2). Our adjusted OR (2.3) for DRC as a continuous variable is within the range of similar ORs values for published studies for basal cell carcinoma skin cancer (Wei et al. 1993), lung cancer (Wei et al. 2000), head and neck cancer (Cheng et al. 1998), prostate cancer ( $\mathrm{Hu}$ et al. 2004) and BC (Shi et al. 2004) [12,26,44,45].

However, when DRC was analyzed either as a dichotomous or as a categorical variable (low, medium, high), the ORs are much higher. Such high ORs are unusual and have been reported only a few studies. For example, Latimer et al. (2010) recently estimated that the sensitivity of detecting tumors based on reduced NER levels alone is $95 \%$, the specificity is $74 \%$, and the odds ratio is 53.8 (95\% CI, 28.3-102.4). This group demonstrated the critical importance of the NER pathway in BC by measuring the NER capacity in breast tumors $(n=19)$ and normal primary cultures expressed relative to the mean of these normal BC tissues. The mean NER capacity of the tumor samples was significantly lower than that of normal breast tissues, averaging only $44 \%$ of normal activity $(P<0.001)$. Some other studies have also reported very high ORs when strong associations are found. This has occurred with the association of cervical cancer with HPV exposure. Some HPV studies have reported very powerful associations. For example, a case control study for HPV by Powell et al. (2011) reported ORs as high as 2770; Chen et al. (2011), as high as 75; Chuang et al. (2012), ORs 18.1 and higher; and Almonte et al. (2011), ORs of 16.1 [46-49].

In this study, we observed an unusually strong increment on the OR after adjustment. Therefore, we repeated the analysis entering, first entering DRC alone in the model; then the covariates were entered one by one. In doing that, we found that the adjusted OR increased gradually as we added each covariate to the model.

No evidence of interaction terms were found in the multivariate logistic model ( $p>0.05)$, so DRC can be considered as a potential independent risk factor for DRC because it is biologically plausible, shows a strong association, and exhibits a dose-response relationship after adjusting for all confounders simultaneously.

Despite the usefulness of the HCR assay to estimate DRC and detect $B C$ risk, future prospective studies are needed to further validate the use of this approach. Specifically, further studies are needed to ascertain 1) whether women without $\mathrm{BC}$ with a low DRC have a higher incidence of $\mathrm{BC}$ compared to those who have a high DRC and 2) whether women with $\mathrm{BC}$ and a low $\mathrm{DRC}$ are at an increased risk of recurrent $\mathrm{BC}$ compared to those with high DRC. 
Table 1 Odds ratio estimation to assess the association between breast cancer (BC) and DNA repair capacity (DRC) and other selected variables in women with BC $(n=285)$ and women without $B C(n=539)$

\begin{tabular}{|c|c|c|c|c|c|}
\hline Variable & $\begin{array}{l}\text { Women with } \\
\text { BC } \mathrm{n} \text { (mean) }\end{array}$ & $\begin{array}{c}\text { Women without } \\
\text { BC n (mean) }\end{array}$ & $\begin{array}{c}\text { Crude OR }{ }^{1} \\
(95 \% \mathrm{Cl}) \\
\end{array}$ & $\begin{array}{c}\text { Adjusted OR } \\
(95 \% \mathrm{Cl})\end{array}$ & $\begin{array}{c}P \\
\text { value }\end{array}$ \\
\hline Age (continuous)* & $285(56.7)$ & $539(52.4)$ & $1.02(1.02,1.04)$ & $1.02(1.01,1.05)$ & 0.001 \\
\hline Number of children & $273(2.4)$ & $517(2.1)$ & $1.2(1.1,1.3)$ & $1.1(1.0,1.3)$ & 0.055 \\
\hline \multicolumn{6}{|l|}{ \# Missing (34) } \\
\hline Increasing BMI (continuous)* & $284(27.8)$ & $534(27.2)$ & $1.02(0.9,1.1)$ & $1.03(1.0,1.1)$ & 0.118 \\
\hline \multicolumn{6}{|l|}{ \# Missing (6) } \\
\hline \multicolumn{6}{|l|}{ Family history of $\mathrm{BC}$} \\
\hline Yes & 64 & 78 & $1.7(1.2,2.5)$ & $1.7(1.0,2.8)$ & 0.054 \\
\hline No & 221 & 461 & & & \\
\hline \multicolumn{6}{|l|}{ Marital status } \\
\hline Married & 154 & 362 & Referent & Referent & \\
\hline Single & 61 & 92 & $4.2(2.2,7.8)$ & $5.9(2.3,15.6)$ & $<0.001$ \\
\hline Divorced & 40 & 66 & $2.7(1.4,5.3)$ & $3.6(1.2,10.5)$ & 0.025 \\
\hline Widow & 30 & 17 & $2.9(1.4,5.9)$ & $4.6(1.6,13.7)$ & 0.006 \\
\hline \multicolumn{6}{|l|}{ \# Missing (2) } \\
\hline \multicolumn{6}{|l|}{ Irregular menstrual cycles } \\
\hline Yes & 183 & 320 & $1.2(0.9,1.6)$ & $1.4(0.8,2.2)$ & 0.207 \\
\hline No & 102 & 213 & & & \\
\hline \multicolumn{6}{|l|}{ \# Missing (6) } \\
\hline \multicolumn{6}{|l|}{ History of pregnancy } \\
\hline Yes & 220 & 401 & $1.2(0.8,1.6)$ & $1.4(0.8,2.2)$ & 0.382 \\
\hline No & 65 & 138 & & & \\
\hline \multicolumn{6}{|l|}{ History of breastfeeding } \\
\hline Yes & 122 & 246 & $0.8(0.6,1.1)$ & $0.8(0.5,1.2)$ & 0.256 \\
\hline No & 118 & 194 & & & \\
\hline \multicolumn{6}{|l|}{ \# Missing (144) } \\
\hline \multicolumn{6}{|l|}{ Alcohol intake } \\
\hline Yes & 42 & 98 & $0.8(0.6,1.2)$ & $0.8(0.5,1.7)$ & 0.526 \\
\hline No & 243 & 441 & & & \\
\hline \multicolumn{6}{|l|}{ Smoking } \\
\hline Yes & 37 & 48 & $1.6(0.9,2.4)$ & $1.1(0.6,2.1)$ & 0.707 \\
\hline No & 248 & 491 & & & \\
\hline
\end{tabular}

*Mean values presented in parenthesis.

Comparisons were measured with the crude ${ }^{1}$ and the adjusted ${ }^{2}$ multiple logistic regression odds ratio $(\mathrm{OR})^{3}$ in the total sample divided by patients and women without breast cancer.

${ }^{1}$ Crude or unadjusted analysis: The analysis is carried out without taking into consideration potential confounders.

${ }^{2}$ Adjusted analysis: The analysis is carried out adjusting for the potential effect of all confounding variables simultaneously by using logistic regression model. The associations were adjusted by DRC, age, body mass index, family history of breast cancer, number of children, marital status, and/or smoking.

In this study, patients were evaluated for DRC after $\mathrm{BC}$ was diagnosed; thus, reverse causation could be present if BC lowers DRC, which would explain why we found a low DRC associated with BC. Nevertheless, reverse causation is an unlikely explanation of our findings because experimental evidence demonstrates that a low DRC or impairments in DNA repair pathways and/or genes is a mechanistic component involved in $\mathrm{BC}$ carcinogenesis $[2,11,28,50,51]$ or relapse [24] for the transition to hormone independence [52].

Given that newly diagnosed patients are not always truly incident patients, we compared DRC results to tumor size (data not shown) as a surrogate for the length of time period between disease onset and diagnosis to address the potential changes that DRC in lymphocytes might have had after a woman develops BC. With these 
Table 2 DNA Repair Capacity (DRC) of women with breast cancer (BC) and women without BC by age group

\begin{tabular}{|c|c|c|c|c|c|}
\hline Variable & $\begin{array}{c}\text { Women with } \\
\text { BC n (mean DRC) }\end{array}$ & $\begin{array}{l}\text { Women without } \\
\text { BC n (mean DRC) }\end{array}$ & $\begin{array}{c}\text { Crude OR }{ }^{1} \\
(95 \% \mathrm{Cl})\end{array}$ & $\begin{array}{c}\text { Adjusted OR } \\
(95 \% \mathrm{Cl})\end{array}$ & $\begin{array}{c}P \\
\text { value } \\
\end{array}$ \\
\hline Decreasing DRC (continuous)* & $285(2.41)$ & $539(6.13)$ & $2.2(1.9,2.4)$ & $2.3(2.0,2.6)$ & $<0.001$ \\
\hline \multicolumn{6}{|l|}{ DRC } \\
\hline $\operatorname{Low}(<4.3 \%)$ & 246 & 168 & $13.9(9.4,20.4)$ & $15.1(10.0,22.9)$ & $<0.001$ \\
\hline High $(\geq 4.3 \%)$ & 39 & 371 & & & \\
\hline \multicolumn{6}{|l|}{ DRC levels ${ }^{3}$} \\
\hline Low (0.0-3.0\%) & 213 & 66 & $54.6(30.3,98.5)$ & $60.6(32.1,114.6)$ & $<0.001$ \\
\hline Medium (3.01-5.8\%) & 57 & 219 & $4.4(2.4,8.0)$ & $13.0(8.5,20.0)$ & $<0.001$ \\
\hline High ( $\geq 5.81 \%)$ & 15 & 254 & Referent & Referent & \\
\hline
\end{tabular}

*Mean values presented in parenthesis.

Comparisons were measured with the crude ${ }^{1}$ and the adjusted ${ }^{2}$ multiple logistic regression odds ratio (OR) in the total sample divided by patients and women without breast cancer.

${ }^{1}$ Crude or unadjusted analysis: The analysis is carried out without taking into consideration potential confounders.

${ }^{2}$ Adjusted analysis: The analysis is carried out adjusting for the potential effect of all confounding variables simultaneously by using logistic regression model.

${ }^{3}$ Chi-Square for linear trend $=233.6, p<0.001$.

analyses, we did not find any statistically significant DRC level differences by tumor size that could interfere with our comparisons.

DRC at its cutoff point selected based on its median value (4.3\%) was found in this study to have $83.2 \%$ sensitivity and $77.6 \%$ specificity for detecting BC. ROC analysis showed a high accuracy detecting $\mathrm{BC}(88.4 \%$ of the area under the curve), which was statistically significant. Because any given specific value of DRC level is associated with a quantitative $\mathrm{BC}$ risk estimate, DRC has the potential to be a biomarker to rule out $\mathrm{BC}$ risk in low-prevalence or low-risk populations or confirm its presence in high-prevalence or highrisk populations. However, a higher specificity and sensitivity would increase the value of DRC as a detector of $\mathrm{BC}$. In addition, these findings need to be validated in other populations and with future prospective studies.

\section{Conclusions}

Our findings confirm the hypothesis that a low DRC is an important risk factor for $\mathrm{BC}$. Thus, measuring DRC could be a useful tool to assess $\mathrm{BC}$ risk, especially in women from low-prevalence or low-risk populations, such as the population that we studied. For every percent unit of decrease in DRC, there is $64 \%$ more likelihood of having BC. Although our results support the validity of using $\mathrm{DRC}$ level to estimate $\mathrm{BC}$ risk, further studies (including prospective studies) are needed to verify whether such an appraisal would be a useful addition to existing screening and risk-assessment tests for BC, as other covariates (for example, family history, age at first pregnancy) could modify its predictive value.

\section{Abbreviations}

BC: Breast cancer; DRC: DNA repair capacity; HCR: Host cell reactivation assay; LUC: Luciferase; NER: Nucleotide Excision Repair.

\section{Competing interest}

Two of the authors (JM, MB) were awarded have received a utility patent award (US 8,163,473 B2) from the United States Patent Trade Office for some findings presented in this manuscript.

\section{Authors' contributions}

The experiments were performed by EN, LM. Participant recruitment and administration of epidemiological questionnaire was done by WV. JD explained DRC results to some participants, performed ancestry marker analysis and helped with DRC assay internal validation. Participant clinical samples were provided by ME, FSG, ERL, AT, JOR, GB, JGC, JL, RB, SSM, AR and RM. Study design, supervision and preparation of manuscript was done by JM. Epidemiological and biostatistical analysis was done by MB, ES and CA. Manuscript preparation was done by JM and MB. All authors read and approved the final manuscript.

\section{Disclaimer}

The opinions and assertions presented in this article are the private views of the authors and are not to be construed as conveying either official endorsement or criticism by the US Department of Health and Human Services, the Public Health Service, or the US Food and Drug Administration.

\section{Acknowledgments}

This study was supported by grants from the NIH-MBRS Program grant \#: S06 GM008239-20 and \#: SC1 ISA157250-01. Both grants were co-funded by the Diversity Training Branch of the National Cancer Institute to the Ponce School of Medicine and Health Sciences (PSHMS) through J. Matta. The authors acknowledge the technical editing of Ms. Rasa Hamilton through the PSM-Moffitt Cancer Center U56 Cancer Partnership Grant (5U56 CA126379-05). Mrs. Heidi Acosta, Ms. Patricia Martinez, Ms. Carmen Ortiz and, Mr. Bob Ritchie (RCMl Publications Office, G12R003050, BR) also provided valuable editorial assistance. We are very grateful for the critical remarks of Dr. Regina Santella, Dr. Susana Silva and Dr. Victor Moreno that substantially improved the quality of this manuscript. The authors also acknowledge the expert editorial assistance of Ms. Lana Christian, CreateWrite Inc. Yeidyly Vergne provided technical assistance. The late Dr. Lawrence Grossman provided much guidance and support in the standardization of this assay and also the plasmid construct. We thank PhD and MD students from PSMHS who helped with various

components of the project during their research rotations. Mrs. Hannia Delgado provided valuable assistance in the recruitment of participants and administrative support as well as in the preparation of this manuscript.

\section{Author details}

'Department of Pharmacology, Physiology, and Toxicology, Department of Surgery, Ponce School of Medicine and Health Sciences, Ponce, Puerto Rico 00732. ${ }^{2}$ Auxilio Mutuo Hospital, San Juan, Puerto Rico. ${ }^{3}$ Department of Surgery and Damas Hospital, Ponce School of Medicine and Health Sciences, 
Ponce, Puerto Rico. ${ }^{4}$ Private Practice, Ponce, Puerto Rico. ${ }^{5}$ Department of Surgery, Ponce School of Medicine and Health Sciences, Ponce, Puerto Rico. ${ }^{6}$ Department of Surgery and Private Practice, Ponce School of Medicine and Health Sciences, Ponce, Puerto Rico. ${ }^{7}$ Department of Surgery and San Lucas Hospital, Ponce School of Medicine and Health Sciences, Ponce, Puerto Rico. ${ }^{8}$ Outpatient Clinics, Ponce School of Medicine and Health Sciences, Ponce, Puerto Rico. ${ }^{9}$ Dr. Pila Hospital, Ponce, Puerto Rico. ${ }^{10}$ Department of Biochemistry, Ponce School of Medicine and Health Sciences, Ponce, Puerto Rico. ${ }^{11}$ School of Public Health, University of Puerto Rico, Medical Sciences Campus, San Juan, Puerto Rico. ${ }^{12}$ Public Health Program, Ponce School of Medicine and Health Sciences, Ponce, Puerto Rico. ${ }^{13}$ Current address: Division of Epidemiology/OSB/CDRH, Food and Drug Administration, Silver Spring, Maryland, USA.

Received: 6 December 2011 Accepted: 15 October 2012 Published: 22 October 2012

\section{References}

1. Ferlay J, Bray F, Pisani P, Parkin DM: GLOBOCAN 2000: Cancer Incidence, Mortality and Prevalence Worldwide, Version 1.0. IARC CancerBase No. 5. Lyon: IARCPress; 2001. Limited version available from: URL: http://globocan.iarc.fr/ Last updated on 03/02/2001.

2. Jemal A, Siegel R, Xu J, Ward E: Cancer statistics, 2010. CA Cancer J Clin 2010, 60(5):277-300.

3. Torres-Cintron M, Ortiz AP, Perez-lrizarry J, Soto-Salgado M, Figueroa-Valles NR, De La Torre-Feliciano T, Ortiz-Ortiz KJ, Calo WA, Suarez-Perez E: Incidence and mortality of the leading cancer types in Puerto Rico: 1987-2004. P R Health Sci J 2010, 29(3):317-329.

4. Kelley M: Introduction and Overview of DNA Repair Targets: from Bench to Clinic. In DNA Repair in Cancer Therapy: Molecular targets and Clinical Aplications. Firstth edition. Edited by Kelley MR. United States of America: Elsevier Inc; 2012:1-16

5. Grossman L, Wei Q: DRC as a biomarker of human variational responses to the environment. In DNA Repair Mechanisms: Impact on Human Diseases and Cancer. Edited by Vos J-MH. Austin: R.G. Landes Company; 1994:329-347.

6. Athas WF, Hedayati MA, Matanoski GM, Farmer ER, Grossman L: Development and field-test validation of an assay for DNA repair in circulating human lymphocytes. Cancer Res 1991, 51(21):5786-5793.

7. Helzlsouer KJ, Harris EL, Parshad R, Perry HR, Price FM, Sanford KK: DNA repair proficiency: potential susceptiblity factor for breast cancer. J Natl Cancer Inst 1996, 88(11):754-755.

8. Jyothish B, Ankathil R, Chandini R, Vinodkumar B, Nayar GS, Roy DD, Madhavan J, Nair MK: DNA repair proficiency: a potential marker for identification of high risk members in breast cancer families. Cancer Lett 1998, 124(1):9-13.

9. Matta JL, Villa لL, Ramos JM, Sanchez J, Chompre G, Ruiz A, Grossman L: DNA repair and nonmelanoma skin cancer in Puerto Rican populations. J Am Acad Dermatol 2003, 49(3):433-439.

10. Patel RK, Trivedi AH, Arora DC, Bhatavdekar JM, Patel DD: DNA repair proficiency in breast cancer patients and their first-degree relatives. Int J Cancer 1997, 73(1):20-24.

11. Ramos JM, Ruiz A, Colen R, Lopez ID, Grossman L, Matta JL: DNA repair and breast carcinoma susceptibility in women. Cancer 2004, 100(7):1352-1357.

12. Wei Q, Matanoski GM, Farmer ER, Hedayati MA, Grossman L: DNA repair and aging in basal cell carcinoma: a molecular epidemiology study. Proc Natl Acad Sci USA 1993, 90(4):1614-1618.

13. Wei Q, Matanoski GM, Farmer ER, Hedayati MA, Grossman L: DNA repair and susceptibility to basal cell carcinoma: a case-control study. Am J Epidemiol 1994, 140(7):598-607.

14. Wei Q, Cheng L, Hong WK, Spitz MR: Reduced DNA repair capacity in lung cancer patients. Cancer research 1996, 56(18):4103-4107.

15. Wei Q, Lee JE, Gershenwald JE, Ross MI, Mansfield PF, Strom SS, Wang LE, Guo Z, Qiao Y, Amos Cl, et al: Repair of UV light-induced DNA damage and risk of cutaneous malignant melanoma. J Natl Cancer Inst 2003, 95(4):308-315

16. Helleday T, Petermann E, Lundin C, Hodgson B, Sharma RA: DNA repair pathways as targets for cancer therapy. Nat Rev Cancer 2008, 8(3):193-204.

17. Hu Z, Wang L, Wei Q, Chen Q: Molecular epidemiology of DNA repair and cancer susceptibility. In DNA Repair, Genetic Instability and Cancer. Edited by Qingyi Wei Q, Lei L, David J, Chen Q. Singapore: World Scientific Publishing Co. Pte. Ltd; 2007:315-343.
18. Benhamou S, Sarasin A: Variability in nucleotide excision repair and cancer risk: a review. Mutat Res 2000, 462(2-3):149-158.

19. Murray D, Berg AC: Relationship among DNA repair genes, cellular radiosentitivity, and the response of tumors and normal tissues to radiotherapy. In DNA Repair in Cancer Therapy. Edited by Kelley MR. New York: Humana Press: 2004:211-256.

20. Mohrenweiser HW, Jones IM: Variation in DNA repair is a factor in cancer susceptibility: a paradigm for the promises and perils of individual and population risk estimation? Mutat Res 1998, 400(1-2):15-24.

21. Ramos J, Villa J, Ruiz A, Armstrong R, Matta J: UV dose determines key characteristics of nonmelanoma skin cancer. Cancer Epidemiol Biomarkers Prev 2004, 13(12):2006-2011.

22. Latimer JJ, Johnson JM, Kelly CM, Miles TD, Beaudry-Rodgers KA, Lalanne NA, Vogel VG, Kanbour-Shakir A, Kelley JL, Johnson RR, et al: Nucleotide excision repair deficiency is intrinsic in sporadic stage I breast cancer. Proc Natl Acad Sci USA 2010, 107(50):21725-21730.

23. Kovacs E, Stucki D, Weber W, Muller H: Impaired DNA-repair synthesis in lymphocytes of breast cancer patients. Eur J Cancer Clin Oncol 1986, 22 (7):863-869.

24. Le Scodan R, Cizeron-Clairac G, Fourme E, Meseure D, Vacher S, Spyratos F, de la Lande B, Cvitkovic F, Lidereau R, Bieche I: DNA repair gene expression and risk of locoregional relapse in breast cancer patients. Int J Radiat Oncol Biol Phys 2010, 78(2):328-336.

25. Xiong P, Bondy ML, Li D, Shen H, Wang LE, Singletary SE, Spitz MR, Wei Q: Sensitivity to benzo(a)pyrene diol-epoxide associated with risk of breast cancer in young women and modulation by glutathione $S$-transferase polymorphisms: a case-control study. Cancer Res 2001, 61(23):8465-8469.

26. Shi Q, Wang LE, Bondy ML, Brewster A, Singletary SE, Wei Q: Reduced DNA repair of benzo[a]pyrene diol epoxide-induced adducts and common XPD polymorphisms in breast cancer patients. Carcinogenesis 2004, 25(9):1695-1700.

27. Motykiewicz G, Faraglia B, Wang LW, Terry MB, Senie RT, Santella RM: Removal of benzo(a)pyrene diol epoxide (BPDE)-DNA adducts as a measure of DNA repair capacity in lymphoblastoid cell lines from sisters discordant for breast cancer. Environ Mol Mutagen 2002, 40(2):93-100.

28. Kennedy DO, Agrawal M, Shen J, Terry MB, Zhang FF, Senie RT, Motykiewicz G, Santella RM: DNA repair capacity of lymphoblastoid cell lines from sisters discordant for breast cancer. J Natl Cancer Inst 2005, 97(2):127-132.

29. Szklo M, Nieto FJ: Epidemiology: Beyond Basics. Boston: Jones and Bartlett; 2007.

30. Rothman KJ, S Greenland LT: Modern Epidemiology. 3rd edition. New York: Lippincott Williams \& Wilkins; 2008.

31. van Loon AA, Timmerman AJ, van der Schans GP, Lohman PH, Baan RA: Different repair kinetics of radiation-induced DNA lesions in human and murine white blood cells. Carcinogenesis 1992, 13(3):457-462.

32. Leprat FAC, Rosselli F: Impaired DNA repair as assessed by the "comet" assay in patients with thyroid tumors after a history of radiation therapy: a preliminary study. Int J Radiat Oncol Biol Phys 1998, 40:1019-1026.

33. Bosken $\mathrm{CH}$, Wei QY, Amos Cl, Spitz MR: An analysis of DNA repair as a determinant of survival in patients with non-small-cell lung cancer. J Natl Cancer Inst 2002, 94(14):1091-1099.

34. Hall J, English DR, Artuso M, Armstrong BK, Winter M: DNA repair capacity as a risk factor for non-melanocytic skin cancer-a molecular epidemiological study. Int J Cancer 1994, 58(2):179-184.

35. Spitz MR, Wu X, Wang Y, Wang LE, Shete S, Amos Cl, Guo Z, Lei L, Mohrenweiser $\mathrm{H}$, Wei $\mathrm{Q}$ : Modulation of nucleotide excision repair capacity by XPD polymorphisms in lung cancer patients. Cancer Res 2001, 61(4):1354-1357.

36. Cheng L, Eicher SA, Guo ZZ, Hong WK, Spitz MR, Wei QY: Reduced DNA repair capacity in head and neck cancer patients. Cancer Epidemiol Biomarkers Prev 1998, 7(6):465-468.

37. Landi MT, Baccarelli A, Tarone RE, Pesatori A, Tucker MA, Hedayati M, Grossman L: DNA repair, dysplastic nevi, and sunlight sensitivity in the development of cutaneous malignant melanoma. J Natl Cancer Inst 2002, 94(2):94-101.

38. Qiao Y, Spitz MR, Guo Z, Hadeyati M, Grossman L, Kraemer KH, Wei Q: Rapid assessment of repair of ultraviolet DNA damage with a modified host-cell reactivation assay using a luciferase reporter gene and correlation with polymorphisms of DNA repair genes in normal human lymphocytes. Mutat Res 2002, 509(1-2):165-174.

39. Rosner B: Fundamentals of Biostatistics. 6th edition. Pacific Grove (CA): Duxbury Press; 2005 
40. Metz CE: Basic principles of ROC analysis. Semin Nucl Med 1978, 8(4):283-298.

41. Zweig MH, Campbell G: Receiver-operating characteristic (ROC) plots: a fundamental evaluation tool in clinical medicine. Clin Chem 1993, 39(4):561-577.

42. Griner PF, Mayewski RJ, Mushlin Al, Greenland P: Selection and interpretation of diagnostic tests and procedures. Principles and applications. Ann Intern Med 1981, 94(4 Pt 2):557-592.

43. D'Errico M, Calcagnile A, lavarone I, Sera F, Baliva G, Chinni LM, Corona R Pasquini P, Dogliotti E: Factors that influence the DNA repair capacity of normal and skin cancer-affected individuals. Cancer Epidemiol Biomarkers Prev 1999, 8(6):553-559.

44. Wei Q, Cheng L, Amos Cl, Wang LE, Guo Z, Hong WK, Spitz MR: Repair of tobacco carcinogen-induced DNA adducts and lung cancer risk: a molecular epidemiologic study. J Natl Cancer Inst 2000, 92(21):1764-1772.

45. Hu JJ, Hall MC, Grossman L, Hedayati M, McCullough DL, Lohman K, Case LD: Deficient nucleotide excision repair capacity enhances human prostate cancer risk. Cancer Res 2004, 64(3):1197-1201.

46. Powell NG, Hibbitts SJ, Boyde AM, Newcombe RG, Tristram AJ, Fiander AN: The risk of cervical cancer associated with specific types of human papillomavirus: a case-control study in a UK population. Int $J$ Cancer 2011, 128(7):1676-1682.

47. Chen HC, Schiffman M, Lin CY, Pan MH, You SL, Chuang LC, Hsieh CY, Liaw $\mathrm{KL}$, Hsing AW, Chen CJ: Persistence of type-specific human papillomavirus infection and increased long-term risk of cervical cancer. J Natl Cancer Inst 2011, 103(18):1387-1396.

48. Almonte M, Ferreccio C, Gonzales M, Delgado JM, Buckley CH, Luciani S, Robles SC, Winkler JL, Tsu VD, Jeronimo J, et al: Risk factors for high-risk human papillomavirus infection and cofactors for high-grade cervical disease in Peru. Int J Gynecol Cancer 2011, 21(9):1654-1663.

49. Chuang LC, Hu CY, Chen HC, Lin PJ, Lee B, Lin CY, Pan MH, You SL, Hsieh $C Y$, Chen CJ: Associations of human leukocyte antigen class II genotypes with human papillomavirus 18 infection and cervical intraepithelial neoplasia risk. Cancer 2012, 118(1):223-231.

50. Sinha S, Singh RK, Alam N, Roy A, Roychoudhury S, Panda CK: Alterations in candidate genes PHF2, FANCC, PTCH1 and XPA at chromosomal 9q22.3 region: pathological significance in early- and late-onset breast carcinoma. Mol Cancer 2008, 7:84

51. Pooley KA, Baynes C, Driver KE, Tyrer J, Azzato EM, Pharoah PD, Easton DF, Ponder BA, Dunning AM: Common single-nucleotide polymorphisms in DNA double-strand break repair genes and breast cancer risk. Cancer Epidemiol Biomarkers Prev 2008, 17(12):3482-3489.

52. Martin L, Coffey M, Lawler M, Hollywood D, Marignol L: DNA mismatch repair and the transition to hormone independence in breast and prostate cancer. Cancer Lett 2010, 291(2):142-149.

doi:10.1186/1471-2407-12-490

Cite this article as: Matta et al:: The association of DNA Repair with breast cancer risk in women. A comparative observational study. BMC Cancer 2012 12:490

\section{Submit your next manuscript to BioMed Central and take full advantage of:}

- Convenient online submission

- Thorough peer review

- No space constraints or color figure charges

- Immediate publication on acceptance

- Inclusion in PubMed, CAS, Scopus and Google Scholar

- Research which is freely available for redistribution 